\title{
Rapport Management under Examination in the Context of Medical Consultations in Spain and Britain
}

\author{
María de la O Hernández López \\ Pablo de Olavide University, Seville \\ mariolahl@upo.es
}

\begin{abstract}
This paper is framed within the areas of interactional pragmatics and social psychology of language, with a twofold purpose: on the one hand, applying Rapport Management (Spencer-Oatey, 2000, 2008) to the context of medical consultations in order to disentangle crucial similarities and differences between British and Spanish interactions; with the exception of Sydow Campbell's (2005) study, Rapport Management has not been directly approached in this context. In this sense, it constitutes both a challenge in communication studies and a step forward in a well-known theory that still remains under-explored. On the other hand, Cordella's (2004) voices in medical consultations will prove to be related to the way interlocutors manage rapport in each culture, and therefore, different voices may be relevant in different cultures. This will lead to variation in terms of the three bases of rapport (face, rights and obligations, and interactional goals). Finally, some remarks and limitations of Rapport Management will be discussed so as to give way to a more comprehensive and effective model of communication which may explain both cultural differences and situational variation.
\end{abstract}

\section{Introduction}

It is widely accepted in the literature of pragmatic studies that institutional interactions are not only based on transactional aspects, but also on interactional strategies and rapport building activities (cf. Placencia, 2004) which may provide the interlocutors 
with the tools to achieve their goals in a smooth way: the transactional-interactional (Brown and Yule, 1983; Coupland et al., 1992; Coupland, 2000; Spencer-Oatey, 2008) duality in interaction is necessary even in contexts where there is a clear instrumental, transactional goal. Since it has been demonstrated that the medical consultation setting is characterized by a highly negotiated interaction between doctor and patient and that there is a difference in terms of power and roles adopted (Cordella, 2000; Lehtninen, 2007), there is an interest in maintaining positive rapport between doctor and patient (Sydow Campbell, 2005). However, the way to achieve this varies from culture to culture, and therefore the communicative strategies adopted, together with linguistic choices given in each sociocultural context will vary considerably as well. In relation to linguistic choices, it may be the case that certain conventions have been established as valid in specific cultures; still, the way we communicate and interpret others also depends on cultural values transferred to communication in an automatic way. These values are translated as linguistic strategies unconsciously known by both speaker and hearer. In other words, besides particular goals in interaction, there are different orientations that can be chosen and negotiated throughout interaction and that are culture-bound: rapport enhancement orientation, rapport maintenance orientation, rapport neglect orientation and rapport challenge orientation (Spencer-Oatey, 2008: 28). Because of the common interests of both doctor and patient, the medical consultation would typically correspond to a rapport maintenance or enhancement orientation. Consequently, this will develop into a culturally-bound strategic use of communication.

\section{Rapport Management and Interactional Pragmatics}

Rapport management is a theory of communication first published in 2000 and reexplained in 2008 by Spencer-Oatey as an attempt to overcome the weaknesses that Politeness Theory (Brown and Levinson, 1978, [1987]) involves. She proposes a broadened framework that builds on Brown and Levinson's contribution in relation to the concept of face. Her central argument is based on the fact that a theory of Rapport Management cannot only account for considerations of face as interpersonal needs, but also sociality rights and obligations as social expectancies, and interactional goals, which can be transactional and/or interactional. At the same time, sociality rights may be divided into equity rights and association rights: equity rights are the expectations in relation to what is fair or unfair in human interaction, while association rights are related to how people relate to each other, considering their roles within the activities developed. This is something that, compared to the concept of face, has been underexplored in the literature of communication studies. Even so, face is also understood as a bi-dimensional base of rapport, where quality face refers to what is socially desirable and identity face is related to individual needs, depending on their roles and the way each interlocutor needs to be projected in social situations.

Depending on the considerations interlocutors have in relation to these three bases of rapport, interaction may be developed in different ways, which are always dynamically negotiated by participants in the interaction. Also, Spencer-Oatey (2000, 
2008) acknowledges the complexity of communication by considering many other factors influencing communication, which are dependent on three bases of rapport, namely, conventions on speech act realizations, sociopragmatic interactional principles underlying communication, and the relationship between participants, power, distance, message content, social roles, etc. The way all this is managed in interaction will develop into rapport enhancement, rapport maintenance, rapport neglect or rapport challenge orientation (Spencer-Oatey, 2008:28).

Hence, by considering a perspective where interactional pragmatics and social psychology of language are integrated together, the result is a full panorama of communication with a set of interconnected variables which operate at different levels. This study will explore this perspective, and will attempt to explain how the three bases of rapport are cultural concepts that may lead to different communicative strategies, to such an extent that even the roles or voices (Cordella, 2004a) adopted by doctors and patients may vary considerably.

Even though rapport management has been widely quoted and supported in politeness and cross-cultural studies, in very few cases has this framework been analysed from an empirical perspective. Besides the contributions appearing in the book where this theory is published (Spencer-Oatey, 2000, 2008), its main applications have only appeared in some business studies (Sydow Campbell et al., 2003; Sydow Campbell and White, 2007), a few contributions from the Hispanic world (Hernández López and Placencia, 2004; Fant, 2006) and one study related to doctor-patient interaction (Sydow Campbell, 2005).

In the case of business studies, Sydow Campbell et al., (2003) and Sydow Campbell and White (2007) propose a model of leadership communication based on a compendium of competing values and Rapport Management as tools to improve the relationship between leaders and members of a company. Also, they demonstrate how employees' perceptions of justice as well as emotional responses of anger may be directly related to the communicative behaviour of organizational leaders in a company. In this sense, Rapport Management is increasingly used as a tool to better understand and improve negotiation in business. It is worth noting that this also means a step forward in comparison to Politeness Theory (Brown and Levinson, 1978, 1987) which, far from being a tool for knowing how to manage relations, is rather a descriptive theory of one aspect of communication -face.

In the Pragmatics arena, Hernández-López and Placencia (2004) explain how Sociopragmatic Interactional Principles (SIPs) - the linguistic expression of what is held as appropriate or not in every situation - are value-laden principles motivated by cultural perceptions of face, rights and obligations and task achievement. Thus, face is conceptualized differently in the Spanish and British society in the sense that there is an orientation towards the addressee (cf. House, 2000) in the latter, and therefore there is a need to find consensus with the hearer, keep distance and be indirect, whereas face in the Spanish society is understood as a way of showing camaraderie and spontaneity, which are two positively oriented features of social life among Spaniards. In terms of rights and obligations, there are certain expectations that interlocutors hold and that 
involve modifications in their way of communicating and interpreting messages. For instance, Spanish requests seem to be much more direct than English requests in most of the cases. However, when the request refers to something beyond the role assumed by interlocutors, Spanish speakers prefer to modify their request and perform it in a more indirect way. These are, then, instances of how language is unconsciously modified in terms of the socio-psychological values that interlocutors hold in interaction.

Fant (2006), in turn, offers an alternative model to Rapport Management, where not only already discussed aspects such as quality face or identity face are considered, but also dichotomies such as membership-individuality, face versus identity, territory and agenda, self-orientation versus other-orientation or target addressing versus target avoiding, to name a few. With this, the author attempts to bring about a holistic paradigm as a starting point after all the attacks that Brown and Levinson's (1978, 1987) Politeness Theory have generated, at the same that shows how interpersonal relations are managed in context. According to Fant (2006: 340), "what may be considered the most far-reaching and elaborate alternative to Brown and Levinson's politeness theory is rapport management theory", which reflects not only the concepts gathered by Brown and Levinson, but also a co-constitutional perspective on communication and interpretation, where communication is basically seen as ongoing meaning negotiation. This is the perspective adopted by authors such as Duranti (1997), Arundale (1999, 2006) and Haugh (2007), among others. As Fant states,

a speaker, when formulating an utterance as a contribution to an ongoing interaction, will evaluate and take into account the hearer's state of mind, wants, needs, and so forth, while choosing forms of expression to be interpreted subsequently by the latter. In doing this, the speaker produces a design [...] for an interpretation, hopefully to be implemented by the hearer. The speaker's evaluation is thought of as simultaneously including code choice [...], sentence meaning [...] illocutionary force [...] and rapport [....] (2006: 347).

As far as physicians and patients' interaction is concerned, Sydow Campbell (2005) provides an account of how Rapport Management can be applied to this context, supporting the view that positive communication in medical consultations is of paramount importance to medical care. In this sense, "Rapport Management model helps us explain how professionals succeed or fail to build relationships with clients based on their verbal communication behaviour", as "building relationships is a central concern for professionals” (Sydow Campbell, 2005: 422). Nonetheless, as the present study demonstrates, Rapport Management should not only be applied to professionals but to all the participants in interaction in order to understand the dynamics involved. In other words, selling a product, for instance, implies that there is a clear interest on the part of the sales representative, while a doctor-patient relationship implies that the patient is completely involved and has a clear interest as well. Sydow Campbell's (2005) study is valuable to understand the relationship that exists between Hofstede's (2001) classification of culture, Brown and Levinson's (1987) Politeness Theory and Spencer-Oatey’s (2000) Rapport Management model, illustrated by means of different 
examples. However, it fails to give empirical evidence of communication between doctor and patient as reflected in real data, nor does it explain the interrelation of elements that conform this framework.

Rapport Management is partly motivated by the latest trends in cross-cultural pragmatics, where communication is no longer seen in terms of positive or negative politeness but as a complex and dynamic phenomenon with a multiplicity of variables and factors. Within what is called Interactional Pragmatics (Arundale, 2006) or Interactional Sociolinguistics, a discursive or postmodernist view to politeness may be considered a bridge between traditional, theoretical politeness and the Rapport Management theory, on which the present research is based. The motivation for this evolution lies in limitations associated with politeness (Matsumoto, 1989; Fraser, 1990; Gu, 1990; Hickey 1991; Culpeper, 1996, 2003; Pizziconi, 2006) on the one hand, and the various attempts to explain communication from a monolithic perspective, namely cognitive theories such as Relevance Theory (Sperber and Wilson, 1985), cultural and anthropological (Hofstede, 1994, 2001, 2007) or contrastive studies (Blum-Kulka et al., 1989) on the other. In other words, the management of interpersonal relations within which politeness and face are embedded does not have to be explained from the perspective of a unique area of research: the management of interpersonal relations in communication is, in fact, an area itself, which needs a comprehensive conceptual framework where interpretative, social, cognitive, cultural, situational and individual factors are integrated to explain why and how communication is culturally developed in diverging ways. This perspective rejects predicting a theory a priori and involves a post facto description of reality in communication (Haugh, 2007), where the perceptions of the interlocutors are needed to avoid scientific bias and where meaning is considered to be dynamically (de)constructed and negotiated.

Arundale (1999, 2004, 2006), with his Conjoint Co-Constituing Model of Communication, develops a dynamic framework where face is a relational, rather than individual, concept; it is in fact a phenomenon that exists once active interaction between at least two people occurs. At the same time, and following Heritage (1984: 242), interactional meaning and face can be either built for the first time (relationshipshaped) or re-established in known relationships (relationship-renewing). It is a move towards interpersonal communication as a dynamically shaped activity which is generating far-reaching frameworks such as the so-called Relational Work (Locher and Watts, 2005; Watts, 2005; Locher, 2006), Face Constitution or Conjoint CoConstituting Model (Arundale, 1999, 2004, 2006) or, ultimately, Rapport Management (Spencer-Oatey, 2000, 2008).

The main reason why the present study has been based on Rapport Management is twofold: there is a need to consider a wide perspective of communication where a variety of elements are integrated and therefore to categorize reality in terms of not only pragmalinguistic and sociopragmatic descriptions but also in terms of interlocutors' attitudes and perceptions of reality; also, we may say that the current theories on interpersonal pragmatics are still focused on the discussion of face, instead of attempting to integrate all those elements that explain communication from $a$ 
multilayered, socio-psychological perspective. Rapport Management is, in fact, a theory where face is one element or rather, one of the three bases of rapport, the other two being sociality rights/obligations and interactional goals. On the other hand, whilst Rapport Management has been proven to be useful in the business arena, it still needs further insights in other institutionalized contexts such as medical consultations. In this sense, this project has been developed under the assumption that Rapport Management, together with Cordella's concept of voice, may provide a robust tool to explain the interactional dynamics between physicians and patients. This paper will demonstrate whether this is a context-transferable framework of communication.

\section{Social Interaction in Medical Consultations}

As stated in the literature of medical consultations, doctor-patient communication is characterized by different roles or voices, i.e., different forms of talk that fulfil various goals in communication. As Misher (1984: 6) explains, this type of linguistic behaviour is associated with the "voice of medicine", as opposed to the "voice of the life-world", where the patient is at the centre of the interaction. It is a context where doctors exercise their control over patients and thus may initiate topics, employ technical words, select and specify the topics to be explored and even interrupt the patient when they deem it to be necessary. This study will also demonstrate that these features of medical consultations are not exactly the same in different cultures and thus, require further examination.

Sydow Campbell (2005) supports the idea that "the most effective physicians are those who fulfil not only the roles of discoverer of pathology and healer (i.e., instrumental behaviours) but also of psychosocial caregiver (i.e., affective behaviours)" (424). Since the doctor - patient interaction is related to topics that are emotionally charged and requires cooperation, it is clear that the amount of positive talk required may be greater than in other contexts where participants are not so involved (Roter and Hall (1992). In this sense, not only must professionals know how to manage rapport effectively in order to achieve their goals, but also how to use linguistic strategies, such as hedging, in order to avoid negative rapport (Sydow Campbell, 2005: 431). This is of special interest not only from a linguistic perspective, but also for medical research, as it is proven that when physicians listen fully and engage in interpersonal communication, the patient's psychological status and physiological symptoms may improve considerably (Steward, 2003).

Cordella (2004a), in turn, identifies three different voices regarding the doctor's role in medical consultations: namely, the doctor voice, which refers to the doctor's role as an information seeker in relation to the patient's symptoms, treatment, medication, lifestyle, etc, as well as providing information and giving the patient the guidelines to improve his or her state of health; the educator voice, which refers to the doctor's role in providing the necessary information to make the patient understand the action he or she should take. According to Cordella (2004a: 59), "the doctor voice and educator voice define medical discourse as different from other forms of talk, as one participant 
is the expert who seeks information, provides treatment, educates and commands authority, while the other participant provides information, complies with treatment, becomes educated and respects authority". A third voice identified by Cordella (2004a: 59 ) is the fellow human voice, which "differs from the other two voices in that its utterances more closely resemble everyday talk [...] [It] does not require any special expertise in order to be carried out successfully, though it is required to display sociocultural competence by knowing how to interact with the patient in a way that develops empathy. This voice differs from the Doctor voice and the Educator voice in that it is likely to be linked to affiliative discourse". Even though this voice is suggested to be peripheral to the medical discourse, the present study will focus on it to demonstrate that it is precisely the fellow human voice that allows positive rapport between participants in interaction and therefore it is even relevant to maintain the authority required to develop the doctor and educator voices. It is, then, an apparently marginal aspect of medical communication, which in fact is the socio-cultural aspect dealing with relational work between doctor and patient.

It is true that the doctor is the participant who has an institutional position and therefore the roles are clear-cut for those interlocutors integrated in the same cultural setting. However, Cordella (2004a: 60) also identifies three different voices for the discourse of patients, which is not characterised by a "structural framework for their forms of talk". Still, the patient may adopt the role of health-related storyteller, the voice of competence, the voice of social communicator and the voice of initiator.

Considering that this paper will develop the socio-cultural aspects in medical interaction that enhance or maintain rapport, this research will also examine how the doctor's fellow human voice interacts with the patient's social communicator and initiator voices to negotiate meaning and manage rapport successfully. In other words, with very few exceptions (Lehtinen, 2007), most studies examining doctor-patient interactions focus on either the talk that doctors perform (Cordella 2000, 2002, 2003), the patients' discourse (Cordella, 2004b) or both, though analysed separately (Cordella, 2004a). This paper will analyse sociopragmatic strategies as interactionally developed by both parties together, in order to not only exchange information or make treatmentrelated decisions, but also create good interpersonal relationships (Ong, De Haes and Lammes, 1995). By taking this perspective, this study will present a holistic point of view where it is not one of the interactants' speech that is at stake but rather the building of rapport and negotiation between doctor and patient, and show how the strategies found serve as the basis to manage positive relations. This paper will then examine how these voices are pragmatically undertaken in Spanish and British consultations to fulfil specific goals. Also, it will demonstrate that the roles adopted by the doctor and patient are not identical in the two cultures, which means that SpencerOatey's (2008) conceptualization of face and sociality rights and obligations varies across cultures. As a consequence, the way rapport is managed in medical consultations is subject to not only specific linguistic choices but also to the way different interactional voices are developed. 


\section{Methodology}

The data analysed consist of 30 interactions between doctor and patient recorded in different geographical areas in England and Spain. The interactions were randomly chosen out of a set of 120 English interactions and 60 Spanish interactions.

The method for data collection varied from one corpus to the other. In the Spanish case, consultations were recorded, after obtaining official permission, in four different healthcare centres in Huelva, Seville, Badajoz and Madrid. Patients had been previously informed of the situation, and only those who agreed to be recorded in subsequent consultations were included in this study. This means that the interactions utilized for this study correspond to follow-up sessions where doctor and patient know each other. Therefore, the type of rapport that is always at stake is relationship-renewing instead of relationship-shaping (Heritage, 1984). Since all those involved had been told about the recording well in advance, by the time the consultation took place most of them had forgotten that they were being recorded and so the naturalness of the interactions did not appear to be distorted.

The English data were taken from the British National Corpus (www.natcorp.ox.ac.uk), which is a collection of 100 million-word interactions collected by the academic consortium Oxford University Press. Some of the features of this corpus are:

1. Monolingual: It covers modern British English, so other languages used in Britain have been discarded.

2. Synchronic: It covers British English from the late twentieth century onwards.

3. General: It includes many different styles and varieties, and is not limited to any particular subject field, genre or register, although it has been categorised in terms of situational aspects and contextual factors. This is why it was very easy to isolate interactions occurring in medical consultations.

4. The data collected are demographically and geographically representative, with an equal number of interactions taken from every region in England.

In both corpora interactions with teenagers and children, as well as initial sessions where the doctor does not know the patient, were not considered as these factors may influence the type of interaction undertaken. Even though the British corpus seems to be more representative statistically (it covers all regions in England) there are reasons to think that the Spanish data are relevant as well, as there is a clear tendency to use similar strategies in most of the interactions analyzed.

\section{Results and Discussion}

As has been stated, both Spanish and English medical consultations are characterized by similar voices which determine how speech is organized. Still, it does not mean that the ways to enhance or maintain rapport are equivalent. In turn, there are considerable 
differences mainly reflecting that the transactional goals to be achieved in medical consultations (seeking advice, gathering information, follow-up of treatment, solving a health problem, etc) are interactionally achieved by means of apparently irrelevant choices in interaction such as the use of jokes, the expression of emotions or the use of small talk, as will be seen later. In this respect, communication in different sociocultural settings is developed in diverging ways due to the fact that, while doctors lead the conversation in British interactions, it is not always the case in socially equivalent Spanish interactions.

As Cordella (2007:194) remarks, the interaction between doctor and patient is based on unequal power relations, which may even be shown in the lexical choices made. This is what is reflected in British interactions, where the doctor clearly leads the interaction not only by asking questions and telling the patient what to do, but also through interactional strategies to show affiliation and empathy. In this sense, the data show how affiliation strategies are initiated by the doctor, who usually makes use of jokes, asks personal questions not necessarily related to the health problem and also takes the initiative to offer help at different points of the interaction. At the same time, the British patient usually adopts a more passive role by waiting for the doctor to lead and guide him/her in the interaction. In contrast, Spanish interactions are not so clearly structured and are not always characterized by the doctor leading the interaction. In fact, it is common to find situations where it is the patient who initiates the conversation and the doctor who just accepts the way the interaction is developed or negotiates what is going to be dealt with. It does not mean that there is no negotiation in British interactions; what it implies is, in fact, that there is more room for disagreement in Spanish interactions and therefore, the interactional work done to negotiate may imply more time and effort on the part of both participants. It will be shown that this is the result of more abstract, underlying cultural conceptualizations of the three bases of rapport specified by Spencer-Oatey (2000, 2008): face, rights and obligations and interactional goals.

After analysing 30 interactions in Spain and Britain, one may say that there are clear differences at various levels of analysis. Even though there are clear differences in speech act realizations and lexical choices in the transaction, these are not the purpose of this paper and therefore they will be left aside. Our purpose is to examine how interactional elements operate in communication in order to achieve particular goals and manage rapport. A series of differences and similarities were found in the data.

\section{1. Small Talk and Humour: doctor or patient as initiator?}

The data show that there are situations where the transaction or fulfilment of communicative goals seems to be separated from interactional activity in the case of small talk. These correspond to spans of time when the doctor undertakes a manual activity such as filling a prescription or examining the patient. This is the moment when one of the interlocutors takes the opportunity to initiate a string of phatic communication or small talk (Coupland, 2000), on occasions unrelated to the health problem itself. Nonetheless, these are at the same time necessary, as the relationship 
between doctor and patient becomes closer, less formal and more 'chatty' from that moment onwards. It works, then, as an ice-breaker where formalisms are combined with casual talk. Even though it happens in both settings, the way it occurs varies significantly.

The Spanish case represents a clear example of interactions where small talk appears with more frequency. In fact, 11 out of the 15 interactions analyzed contained some bits of small talk, sometimes unrelated to the main issue. It is worth noting that these are usually initiated by the patient, and it is the doctor who participates in the interactions with follow-up comments. Sometimes they may correspond to general comments on the patient's problems, but also questions and comments on the doctor's (good) performance as a doctor. In interaction (1), a Spanish patient shows interest in the doctor's performance as a doctor while at the same time commenting on the health centre where they are located (in bold):

\section{(1) (Spain):}

\section{$[\ldots]$}

P: también necesitaba las recetas de siempre

$P$ : I also need the usual prescriptions

D: ¿qué nombre es?

D: what name is it?

P: las de azúcar, las de mareos y eso

$P$ : the ones for sugar, dizziness and all that

((doctor writes the prescription))

\section{P: Don José, es verdad que se va usted}

P: Dr José, is it true that you are leaving

D: pues, es que, como está el tema, eh, así es que no podemos / ya que si no / si no puedo ver a la gente con tranquilidad y con=

D: well, seeing how things are going, we can't work properly/ I cannot/ I cannot attend patients properly and with=

P: de verdad?

P: really?

D: si se arregla / me quedo (1) si no / me iré

D: if everything's sorted out / I'll stay (1) otherwise / I'll leave 
P: esto es un cachondeo cada vez más grande, eh, es que esto es (1) / pues es una pena que se vaya entonces (3) pues ya estamos voy a hacerme las mías de tensión

P: this is not serious, this is (1) / it's a pity if you leave then (3) well, we're done, I'm $[\ldots]$ going to get my blood pressure taken?

Also, small talk may appear in the form of unsolicited personal information, which could be interpreted, on the one hand, as a silence filler, a way to socialize with the doctor once he is busy writing a prescription or examining the patient in silence; on the other hand, it may help enhance rapport with the doctor, as a way of showing gratitude or expressing a more equal relationship: the doctor may ask questions because he or she has an institutional interest in the patient's problems, whereas the patient tries to compensate this by showing personal concern or consideration towards the doctor, as illustrated in the interaction above.

In the case of British interactions, small talk appears as pause filler as well, mainly once the main transactional goal has been fulfilled and generally initiated by the doctor. Nevertheless, small talk appears in only 5 situations out of 15, and therefore it does not seem to be as relevant as in Spanish interactions. In these situations it was the doctor who initiated the phatic communication stage in interaction:

\section{(2) (England)}

$[\ldots]$

D: and you don't need to do anything / keep yourself generally fit / so we'd better make a note of that [...] and then / you are not getting any side effects from Erithramita

P: No side effects / fine as far as I can tell

D: Okay / now you're nineteen aren't you? / you must have finished school

P: I'm going to University

D: I was going to ask what you're doing

P: in September

$[\ldots]$

What these examples reveal is that, even when small talk is a common feature in British and Spanish medical consultations as a general strategy to maintain or enhance rapport, the way they operate is substantially different. To start, the number of interactions containing small talk is higher in Spain; also, Spanish interactions reflect that the patient may take the role of initiator (Cordella, 2004b) whereas the initiator is always the doctor in the case of British interactions. It has implications in relation to power relations and roles that may be discussed in section 6 .

In turn, humour and the use of jokes is a rather frequent strategy reflected in British interactions, where the doctor, the person holding institutional power, is the initiator in 
interactional work. In this case, it is the patient who follows, agrees or laughs as a response to the doctor's jokes. Out of the 15 interactions analysed in England, 9 contained jokes, irony or other humoristic comments, as illustrated in the utterances in bold in interactions (3) and (4):

\section{(3) (England):}

D: Hello, well come in

P: $\mathrm{Oh}$

D: ((looking at patient's personal details)) You're not married yet?

P: yes /cos [...] changing doctors and I'm not changing ((laugh))

D: ((laugh)) you're a bad woman

P: I know cos I'm in now, and you don't do / so I'm not changing

D: well, what can we do for you?

\section{$[\ldots]$}

P: it's / I can't sleep at night

$\mathrm{D}:(\ldots)$

P: Oh I know

D: You appear to enjoy this

P: I know ((laugh))

As can be seen in interaction (3), the doctor classifies his patient as a 'bad woman' for not changing doctor, due to the fact that she is supposed to have the same doctor as her husband. Cultural and contextual aspects are important here in order to understand this conversation (once women are married, they are supposed to have the same doctor as their husbands, so changing doctors is usual). Later on in the conversation, the doctor is ironic about the fact that, instead of emphasizing the negative effects of the patient's health problem, he prefers to do so ironically ('you appear to enjoy this') as a rapport enhancement strategy. It shows how jokes may have the function of not only maintaining/ enhancing rapport but also relieving the possible tension that may exist when dealing with serious health problems. Interaction (4) is another example of this:

\section{(4) (England):}

D: right, what can I do for you this morning?

P: well, erm I I'm still ((laugh)) having panic attacks I've still made a diary of it

D: a merry Christmas, aha

P: ((laugh))

D: Let me have a look 
In this sense, the role identified by Cordella (2004a) in doctors as fellow human voice is reflected in the use of this strategy (among others), as making jokes in interaction with patients implies a certain closeness towards them, a way of minimizing the importance of the health problem and showing, all in all, the human side of the doctor who seems to be the only one expected to initiate interactional work on the fringes of transaction. In contrast, humour and irony were not found in the Spanish interactions examined.

Another case where the British doctor is the social initiator in comparison to Spanish interactions where the patient fulfils this same role is found in the opening stages of conversations: whereas the British case shows how the doctor initiates the transaction by offering his/ her help in 14 interactions, 11 Spanish interactions are initiated by the patient straightaway, as reflected in examples (5) and (6):

\section{(5) (England):}

$\mathrm{D}: \mathrm{Mr}$ / do have a seat / what can I do for you this morning?

P: Well I seem to have a sore throat I can't get rid of.

\section{$[\ldots]$}

\section{(6) (Spain):}

P: Buenos días

P: good morning

D: Buenos días

D: good morning

P: a ver la chica que ha amanecido esta mañana con una fiebre

$P$ :well the child woke up with a temperature this morning

D: sí? Bueno / y qué edad tiene ella?

D: yes? Well / how old is she?

P: siete / y es que hace poco estuvo con una infección de orina con antibióticos

$P$ : seven/ not long ago she had a urine infection and took antibiotics

D: y tiene fiebre desde ayer, no?

D: and she's had a temperature since yesterday, is that right?

P: desde esta madrugada.

$P$ : since early this morning 
Again, the British doctor is doing his job at the same time as he shows concern for his patient at a very early stage in the interaction. In the case of Spanish interactions, the doctor also reflects the role of human fellow by listening to the patients' problems, asking followup questions and listening actively, though not necessarily by initiating the interaction.

\section{2. The patient as Social Communicator and Decision-Maker.}

Apart from the fact that Spanish patients are initiators in interaction with doctors, they prove to be social communicators as well, as reflected in three main strategies: the expression of emotions, showing concern for the doctor and eliciting personal information that is unrelated to the transaction.

Regarding the first feature, the data show that Spanish patients usually express their feelings or concern in relation to health problems or other matters in a spontaneous unsolicited way. In line with García Gómez (2008), the expression of emotions could be seen as directly related to cultural values: whereas the Spanish culture views the expression of feelings and emotions as a self-affirmation strategy (Hernández López and Placencia, 2004; Fant, 1989), the British culture is based on the assumption that modesty and approbation are part of social behaviour and therefore the expression of emotions may even be seen as a sign of weakness or lack of credibility. According to García Gómez (2008:1347), “this cultural-relativistic dimension is clearly reflected in differences in the way in which the self is constructed and how social relationships are understood". This is what happens in 10 Spanish interactions. In the case of British interactions, only 2 cases included the expression of emotions. Still, both corpora show that the doctor's role is to generally agree, listen to and reassure the patient. This, then, clearly shows that the voices that both doctor and patient represent cannot be explained separately, as one may be the consequence of the other. In this particular case, the role of social communicator that the patient represents requires an answer from the doctor, which in turn reflects the fellow human voice described by Cordella (2004a). Interactions (7) and (8) are examples of patients showing their emotions or somebody else's emotions in relation to health:

\section{(7) (Spain)}

\section{$[\ldots]$}

P: no puedo trabajar ni nada?

$P$ : can't I work or anything?

D: ahora no

D: not at the moment

P: eso es lo que me tiene a mí agobiado.

$P$ : this is what stresses me out 
D: Sí, pero ya cuanto te pongas bien pues empezarás a trabajar otra vez / pues una persona mala no puede empezar a trabajar

D: yes, but las soon as you recover you can start work again / but you can't work when you're ill.

P: eso es lo que me tiene a mí agobiado y [[muy nervioso]]

P: this is what makes me feel so stressed [[very nervous]]

D:

$$
\begin{array}{r}
[\text { claro }]] \\
{[[\text { of course }]]}
\end{array}
$$

P: es verdad, eh?

$P$ : it's true, isn't it?

D: hombre / pero tienes que ponerte bien / después ya pues haces tu vida normal otra vez / vale? / bueno / [[Juan Antonio

D: well/ but you have to recover first / then you'll be able to have a normal life again / ok? / well [[ Juan Antonio

P: $\quad[$ [vale, muchas gracias

[[ok, thank you

D: no vayas a volver a fumar, eh?

D: don't start smoking again, will you?

$\mathrm{P}$ : vale / a ver si me puedo contener porque me tiene agobiado eso

P: ok / I'll try not to because that is what stresses me out

D: tienes que conseguirlo, eh? Hombre, claro que sí

D: you have to manage it, O.k? Of course you will

$\mathrm{P}:$ vale / gracias, eh?

P: ok / thank you

D: vale

D: ok

(8) (Spain)

$[\ldots]$

P: y ya está / no ha cambiado no ni nada, no? 
P: that's all / nothing has changed, has it?

D: no / sigue igual todo / sigue igual / está muy bien la analítica

D: no / everything is as before / the blood test is fine

P: es que ella estaba muy preocupada porque tú sabes que a ella le pasó algo parecido y le dijeron tienes cáncer de ovarios y la operaron, no?

$P$ : well she was very worried because you know something similar happened to her and they told her she had ovarian cancer and she was operated on, right?

D: la operaron hace mucho tiempo pero no tiene nada que ver.

D: she was operated on a long time ago and it has no relation to this

P: ella se pone “ a mí me sacaron un cáncer” / que tú sabes cómo son las viejas

$P$ : she says "they found I had cancer" / you know how old people are

D: sí

D: yes

P: y digo / bueno Matilde pero / para ellos esos términos son así / no

$P$ : and I say / well Matilde but/ but for them this is like that

D: claro

D: of course

P: total y estaba preocupadilla ella / ya llevas unos pocos de días aquí, no?

$P$ : so, she was worried / you've been here for some days, haven't you?

D: ya sí / ya sí / es que ya acabé que estaba de baja de asuntos propios

D: yes / yes / my days off are over already

P: ah

P: aha

D: ya sí, ya vuelvo otra vez

D: yes I'm back again

P: muy bien

$P:$ good

D: esto es lo que quieres / ahí va

$D$ : this is what you want / here you are

((writes prescriptions)) 
Interaction (9), in turn, represents one of the few examples found in British interactions where emotions were shown in relation to the patient's child. Again, a way to reassure the patient in the case of British interactions is to use humour, as can be appreciated in bold at the end of the interaction:

\section{(9) (England)}

D: What can I do for you this morning?

P: Well I seem to have a sore throat I can't get rid of / I've had it for three weeks / I've got bad breath and it's all like coming down here and in my ear (1) but the thing that concerned me, my little lad's had tonsillitis three times on the trot / and I'm

D: ((cough))

P: wondering whether it's I'm giving it to him / to him or what / I don't know whether I am or not

D: is he giving it to you / or are you giving it to him

P: I don't know / but he can't shake it off /he's had antibiotics right / three times / and he's still got it.

\section{$[\ldots]$}

D: open your mouth for me / say ah

P: ah

D: yes / very nasty looking (2) okay / let's have a quick look around the rest of your mouth (2) would you breathe out for me?

P: yeah

\section{$[\ldots .$.}

D: so your breath is fine / your teeth are fine / your gums are fine / your tongue's fine but your tonsils look very unhealthy / they really look nasty / this is what I suggest you do

\section{$[\ldots]$}

D: and if I come down? with a sore throat now / I know who to blame ((laugh))

P: ((laughing)) yeah

\section{$[\ldots]$}


Another related feature in Spanish interactions is the fact that patients spontaneously give or ask questions about personal information, experiences and relatives, as in interaction (10). As previously explained, this may also occur in British interactions. Nevertheless, apart from the fact that the initiators are different in both settings, the frequency of occurrence is also higher in Spanish than in English. Also, this is sometimes combined with the fact that it is the patient who shows interest in the doctor's well-being, relatives, etc. These are examples of how patients both adopt the roles of social communicators and initiators and guide the interaction simultaneously. In interaction (10), the patient shows concern for the doctor's well-being and his relatives at the same time that she expresses her emotions and judgement in relation to the doctor's performance:

\section{(10) (Spain)}

P: buenos días

P: good morning

D: buenos días

D: good morning

\section{$P$ : uy que alegría verlo a usted}

P: I'm very pleased to see you

D: ((laugh))

P: con usted / esto usted lo espabila en un momento (1) me tiene usted que hacer unas recetas

P: with you /this will get sorted out quickly (1) you have to give me some prescriptions

D: muy bien

D: fine

P: [ [dos / cuatro / seis

$P:$ two/ four / six

D: [[todas estas son suyas / verdad

D: all these are yours / aren't they

P: sí / y esta de mi marido

$P$ : yes / and this one is my husband's

D: muy bien / y su nombre es / o sea su apellido

D: OK / and your name is / I mean your surname 
P: Domitila Pérez Romero

P: Domitila Pérez Romero

D: Qué edad tenía, Domitila?

D: how old are you, Domitila?

P: sesenta y ocho

P: sixty-eight

D: muy bien

D: right.

P: la familia bien, no don José

$P$ : everything fine in your family, Don José?

D: está bien está bien / y ustedes como andáis por ahí?

D: fine, fine / what about you?

P: vaya

$P$ : so so

((pause))

P: estamos liados ahora con la medicina interna y -

$P$ : now we are having problems with internal medicine

[...]

P: bueno ((pausa))

$P$ : well ((pause))

((doctor writes the prescription))

P: hoy ya le queda poco tiempo aquí

$P$ : you're almost finished here for today.

D: sí ((pausa))

D: yes ((pause))

P: ((sighing))

D: pues muy bien

D: good 
P: muy bien / muchas gracias / Don José

P: good / thank you / Dr José

D: de nada / bueno / hasta luego

D: you are welcome / well / see you

P: adios

P: goodbye

Apart from these features, the Spanish data show it would be necessary to include another voice or role not directly mentioned by Cordella (2004a) in her study: the patient as decision-maker ${ }^{1}$. It corresponds to situations where the patient, after explaining the symptoms, makes an evaluation of the kind of problem he or she may have, together with possible measures to follow and/or a specific treatment. Similarly, Young and Flower (2002) define patients as "problem solvers". The term 'decisionmaker' is preferred here because it does not make reference to the solution of problems but to the initiative taken to make decisions, whatever they are. It is, at least potentially, a very controversial point in the interaction, as the doctor may feel obliged to contradict the patient at times, if he or she sees the diagnosis is not appropriate or there is something else that should be done. This is one of the situations that may contradict the widely-known Politeness Theory (Brown and Levinson, 1978, 1987), as imposing and in a way supplanting the role of the doctor is not seen as problematic in this context. What is more, it is a situation that is completely naturalized and integrated in the Spanish setting, where the patient may take the initiative to develop these voices, while the doctor, due to the institutional role he or she represents, may restore his authority by agreeing or disagreeing with what the patient proposes. This fact is also important to understand why cultures make different uses of speech acts; in particular, we could affirm that Spanish contains more disagreement expressions than British, as expressed in Hernández López and Placencia (2004) in the context of service encounters, for instance. However, once it is understood that Spanish holds self-affirmation as a positive value, by means of which interlocutors may express what they feel and apparently take decisions, it is also clear that a disagreement expression may follow at times. In turn, if the British culture is generally characterized by searching for public consensus, what follows is that both doctor and patient want to stick to the roles in the frame in which they are embedded, and therefore these features are not significantly frequent. Examples of how patients make decisions can be seen in example (11) (in bold):

\section{(11) (Spain):}

P: Qué hay, doctor

$P$ : how are you, doctor 
D: adelante, buenos días

D: come in, good morning

P: mira, Don José, que venía a por $((\ldots .)$.

P: look, Mr José, I came here to ((...))

D: qué edad tiene

D: how old are you?

P: yo ya voy a cumplir los años el 9 de diciembre

P: my birthday is 9th December

D: los cuarenta y ...

D: forty...

P: cuarenta y uno

P: forty-one

D: cuarenta y uno

D: forty-one

P: cuarenta y uno (1) Que Don José, que mire usted lo que me pasa

P: forty-one (1) Dr José, look what's happening to me

D: sí

D: yes

P: además de la receta / que a mí me están dando unos mareos por el cuerpo

P: apart from the prescription / I get bouts of dizziness

D: sí

D: yes

P: que esto mejor me parece que tengo una migaja de colesterol, ¿por qué no me mira usted los oídos o?

P: I think I have a bit of cholesterol, why don't you examine my ears?

D: no, hombre

D: no, man

P: ¿por qué no me hace usted una analítica?

$P$ : why don't you send me for a blood test? 
D: no, hombre

D: no, man

P: una vez me subió a 20 la tensión, ehP: my blood pressure went up to 20 once

D: a ver la receta

D: let's see the prescription first

P: era- /dígame usted todo lo que usted sepa de mi enfermedad

$P$ : it was -/ tell me everything you know about my health problem

D: ((writes the prescription))

D: ya hace tiempo que no te haces analítica, verdad, Gregorio

D: it's been a long time since you last had a blood test done, isn't it, Gregorio?

$[\ldots]$

As can be observed in interaction (11), the patient not only expresses what he thinks his health problem is, but also gives suggestions to the doctor in relation to what to do . Even though the doctor's first reaction is a blunt disagreement, little by little they negotiate: while the patient gives reasons to convince the doctor to send him for a blood test, the doctor finally agrees with him.

What can be unravelled from this analysis is that different societies develop different communicative styles (Spencer-Oatey, 2000, 2008), which are directly influenced by the interlocutors' perceptions of rights and obligations and face. These factors, together with the fact that we are dealing with unequal power relationships, will shape different voices in the sociocultural contexts analysed. In other words, Spanish and British patients reveal different attitudes which depend on 1) cultural values embedded in each culture, 2) Sociopragmatic Interactional Principles (Spencer-Oatey and Jiang, 2003) that guide interaction and communicative styles, 3) the interlocutors' perception of rights/ obligations and face in interaction and 4) the type of power relationship developed in the medical consultation, among others.

In relation to this, data show how power may be institutionally given or interactionally achieved: in the case of British interactions, patients accept the intrinsic power of the doctor to lead the conversation, take decisions and give advice. In this sense, patients depend on the doctor's communicative choice in order to know when to participate. In contrast, Spanish interactions show how, even though an unequal power relation is assumed between doctor and patients, the latter feel they can negotiate, take decisions and give opinions as well. It means that patients' attitudes show how power is negotiated and interactionally achieved. It does not mean that the intrinsic power in doctors is not considered. In turn, it reflects that power is a multilayered concept which 
may help understand why the three bases of rapport vary across cultures and, in particular, why speakers have different perceptions of what rights and obligations there are in different communities.

It leads us to understand that, whereas British interactions show consistency in terms of implicit rights and obligations given by the roles adopted in this context, Spanish interactions illustrate how institutional rights and obligations can be combined with interactional rights and obligations, the latter being constantly negotiated but eventually accepted by both parties as a common way to interact in this context. In other words, even though Spanish patients may be aware of the existing unequal power relationship with the doctor, it is also true that they feel they have the right to say what they think, give advice and take decisions. It means that institutional rights and obligations (marked by unequal power relationships) are combined with interactional rights and obligations (which show patients' self-affirmation) in order to achieve successful communication and manage rapport appropriately. In contrast, British patients' attitudes show that there is consistency between institutional and interactional rights and obligations, which are based on a desire for consensus and explicit acceptance of roles.

By contrast, the data analysed reflect that interlocutors have differing ways of managing face needs in interaction. To give an example, the expression of emotions is an illustration of how Spanish interlocutors manage face by means of self-affirmation strategies which allow them to value what they think and feel as positive. In turn, British interlocutors may relate the expression of emotions in the public sphere as a sign of weakness and loss of credibility. These differences are crucial in order to manage rapport adequately and, in this particular situation, to be able to enhance or maintain good relations. This is in line with García Gómez, who adopts a cultural-relativistic approach to the expression of politeness: "[...] the distinct set of strategies used by each culture not only characterizes it but also defines a different conception of FACE for each culture [...] emotion seems to have a distinct value for each culture” (2008: 1342).

\section{Some Remarks on the Management of Rapport.}

It is clear that Rapport Management can be a powerful tool to explain why there is variation across cultures and situations. In fact, it has been shown how the multiplicity of variables included within this theory gives way to a general overview of not only causes and consequences of communicative differences across cultures, but also the complexity of communication itself as a social psychological aspect of human life. Nonetheless, it is worth noting that this is still in need of further elaboration in some respects.

In general terms, Rapport Management offers a comprehensive model of communication but in fact a list of variables as expressed in Spencer-Oatey (2000, 2008) cannot explain how they operate and relate to each other. In this respect, more empirical studies are needed, at the same time that this theoretical framework should be 
able to explain how elements influence each other in order to offer a more complete panorama.

Spencer-Oatey $(2000,2008)$ assumes that the three bases of rapport (face, rights and obligations, interactional goals) operate at the same level. However, there are substantial differences between interactional goals and the other two bases: whereas face and rights and obligations are interactionally managed and only exist in an ongoing interaction, interactional goals are usually pre-established in the interlocutors' minds. What this means is that everybody knows what their and others' goals are in a well-known frame, even though the way they achieve them must be interactionally negotiated. In other words, interactional goals exist in the minds of the interlocutors, whereas face and rights and obligations are social, so they only exist in their minds once the interaction is being developed.

In order to achieve harmony in interaction, it is necessary for both speaker and hearer to share similar conceptualizations of face and rights and obligations or, at least, understand each other's worldview in order to manage rapport properly. At the same time, harmony does not depend on sharing interactional goals, but on managing them properly. Also, we may say that whereas face and rights and obligations are complex concepts related to communicative behaviour, interactional goals are usually specific, as one may clearly know what one wants and expects in interaction, both in interactional and transactional terms. In relation to this, Haugh (2003) explores anticipated versus inferred politeness and face. More empirical research is needed to understand whether rights and obligations are also both anticipated and inferred, as seems to be the case. Also, interactional goals may be anticipated, though the interaction may give room to infer whether interlocutors have other goals not foreseen in advance. In a nutshell, we may say that face and rights and obligations are the medium to manage rapport, whereas interactional goals are in fact the reason why interaction is developed on many occasions.

Although it is true that face and rights and obligations have been fully explained in Spencer-Oatey (2000, 2008), the third base, interactional goals, still needs further clarification. It seems to be simplified to the dichotomy transactional-interactional, but how these two categories are managed is something that has been overlooked. Apart from this, I propose the inclusion of the dichotomy external versus internal goals (García Gómez, 2008), which may contextually vary. For instance, an external goal in a medical consultation may be solving a health problem, while an internal goal may be persuading the doctor to change medication, maintain rapport or eliciting his concern about something physical.

It is worth noting that it is still difficult to clearly differentiate between face (i.e. "people's sense of worth, dignity, honour, reputation, competence and so on") and rights and obligations (i.e., "people's concerns over fairness, consideration, and behavioural appropriateness (Spencer-Oatey, 2008:11), as these depend on each other. According to Spencer-Oatey (2008: 12), “face is closely related to a person's sense of identity or self-concept: self as an individual (individual identity), self as a group member (group or collective identity) and self in relationship with others (relational 
identity)”. Likewise, the author includes "explicit and implicit conceptualizations of roles and positions (2008: 13) as one of the factors within sociality rights and obligations. One may wonder whether there is a boundary between the concept of face as a group member and specific conceptualizations of roles and positions. They do not appear to be clear-cut categories but seem to depend upon each other. Empirical data with real corpora are needed to see how they are interrelated and to know whether they can always be so clearly separated from each other.

Finally, one may wonder why there are three variables, three bases of rapport. What is more, there are some studies (Garcés, 1991, 1993; Forgas 1999; Nieto y Otero, 2003) that show that there are variables such as affect not taken into consideration in politeness studies. This framework would benefit from the same comment: once affect is present in interaction, it is supposedly expected that considerations of face or rights and obligations may change and therefore affect should be considered a higher level variable within Rapport Management. It is not clearly foreseeable whether or not interactional goals are influenced by affect -another difference between the three bases of rapport to take into consideration in future research.

\section{Conclusions}

This paper has examined how institutional settings such as medical consultations may show variation across cultures at different levels related to the way interlocutors manage rapport. It has shown how, whereas British interactions are usually led by the doctor, Spanish interactions may be led by either the doctor or the patient. Also, this study has focused on interactional voices (i.e. those voices that are not directly related to the transaction itself but to the way people manage rapport) to conclude that the doctor's fellow human voice is the central role taken to maintain or enhance rapport, whereas Spanish interactions reflect that the patient's role as social communicator and initiator are the most prominent voices in interaction. We have seen, then, how British doctors take the responsibility to manage rapport through humour, small talk and showing interest in the patient's well-being from the very beginning of the interaction, whilst Spanish interactions show more flexibility in the patterns followed, where patients initiate turns, show their emotions and even give advice on how the doctor should diagnose the health problem treated.

In this sense, not only have different voices been emphasized in both settings, but also different cultural principles underlying communication are seen as relevant here: on the one hand, following Hernández López and Placencia (2004), there is a constant search for self-affirmation in Spanish contexts, where there is a tendency towards informality as compared to British medical consultations, which are characterized by searching for consensus and maintaining formality throughout the interaction. Spanish patients' communicative behaviour shows closeness with the doctor in comparison to British doctors and patients, who usually stick to a more rigid frame. In line with House (2000), this study reflects an orientation towards the addressee in British interactions, while Spanish interactions may be oriented towards the content and the self. 
These differences reveal that speakers hold varying beliefs in relation to what face, rights and obligations and interactional goals are in interaction. In other words, the way interlocutors manage rapport and negotiate varies across cultures even in situations where there is a clear purpose and a common goal (solving a health problem). Even so, the ways interlocutors deal with this vary considerably. It may reflect a difference in the concept of institutional role (more flexible in Spanish than in British settings) and the concept of power (more clear-cut in British than in Spanish societies).

Rapport management has proven to be a robust framework of communication that is able to explain why there are differences in communication styles and cultural beliefs. In this sense, face needs vary across cultures and therefore they need to be managed adequately in order to maintain or enhance rapport in this context. Successful communication, then, will partly depend on sharing and understanding common conceptualizations on the amount of emotions expressed, for example. As for rights and obligations in interactions, the data reflect how British medical consultations are developed in a fixed way where each interlocutor sticks to their corresponding institutional role. In this sense, the doctor has the power to decide not only on treatment related issues, but also on the way doctor and patient will relate and develop their relational work. Contrary to this, Spanish medical consultations seem to be developed in a less structured way where patients may also decide on the course of the interaction by initiating topics, giving advice to the doctor or expressing their emotions. The concept of power varies in the sense that doctors are perceived to have a more humanized role in the Spanish context, where the opportunities to ask about their personal life, evaluate their job and tell them about one's own personal life simply arise with naturalness and a slight hint of informality. In contrast, power relations seem to have a one-to-one relationship with institutional rights and obligations in Britain. These differences are again relevant to understand the interlocutors' face needs.

Even though the results obtained showed that there were common patterns in each of the corpora, it is worth noting that the Spanish corpus should be completed with interactions recorded in other areas of Spain so as to gather a more representative sample. In any case, the fact that there was an equal number of interactions recorded in public and private consultations, as well as towns and cities; that children, teenagers and adults over 70 years old were not included, and that an equal number of male and female doctors were recorded means that the results may be illustrative of this context for middle-aged Spaniards. Hence, a comparison with the British National Corpus may be useful to understand the socio-cultural differences explained in this study.

In a nutshell, this study has shown how Rapport Management can explain similarities and differences in communication, as well as why and how they are shaped in diverging ways. It has been demonstrated that the social psychological bases of rapport (face, rights and obligations, interactional goals) are motivating forces for sociocultural behaviour and pragmalinguistic choices in particular situations. In this sense, separating sociopragmatic from pragmalinguistic aspects of communication may lead to a biased perspective of communication. This framework of analysis is powerful enough to understand the complexity that communication entails in itself at different 
levels: the mere choice of a lexical item may be motivated by sociopragmatic principles and cultural conventions which are the result of specific cultural values in particular societies. Even though this framework is still in need of more empirical research, reexplanation of the variables and understanding on how they operate together, one cannot deny that it is the most elaborate model of communication since the appearance of Brown and Levinson's Politeness Theory. By adopting this holistic point of view, studies like this can be explained -not only described.

\section{Notes}

1. The term decision-maker as referred to patients in medical counselling comes from the area of Health Psychology to refer to patients' involvement in doctors' decision processes. This implies that the options chosen fulfil patients' expectations and value systems (Broadstock \& Michie, 2000, Pierce, 1996).

\section{References}

Arundale, Robert B. (1999): “An alternative model and ideology of communication for an alternative to politeness theory". Pragmatics 9: 119-153.

(2004): "Co-constituting face in conversation: an alternative to Brown and Levinson's politeness theory”. Paper presented to the National Communication Association, Chicago, IL.

. (2006): "Face as relational and interactional: A Communications framework for research on face, facework and politeness”. Journal of Politeness Research 2: 193-216.

Bissel, Paul, R. Carl May and Peter Noyce (2004): "From compliance to concordance: barriers to accomplishing a re-framed model of health care interactions". Social Science and Medicine 58 (4): 851-862.

Blum-Kulka, Shoshana, Juliane House and Gabriele Kasper (1989): "Requests and apologies: a cross-cultural study of speech acts realization patterns (CCSARP)”. Applied Linguistics 5: 192-212.

Broadstock, Marta and Susan Michie (2000): "Processes of patient decision making: theoretical and methodological issues”. Psychology and Health 15: 191-204.

Brown, Penelope and Stephen Levinson ([1978] 1987): Politeness. Some Universals of Language Use. Cambridge: Cambridge University Press.

Brown, Gillian and George Yule (1983): Disourse Analysis. Cambridge: Cambridge University Press.

Cordella, Marisa (1999): "Medical discourse in a Hispanic environment: power andsimpatia under examination”. Australian Review of Applied Linguistics 22 (2): 35-50. . (2002): "La interacción médico-paciente en escrutinio: un estudio de sociolingüística interaccional. Onomazein, 7: 117-144.

(2003): "En el corazón del debate: el análisis del discurso en la representación de las voces médicas”. Oralia. Análisis del Discurso Oral, 6: 147-168. . (2004): "The dynamic consultation. A discourse analytical study of doctor-patient communication”. John Benjamins Publishing: Philadelphia. 
Coupland, Justine, Nikolas Coupland, and Jeffrey Robinson (1992): ““How are you?: negotiating phatic communion”. Language in Society 21: 207-230.

. (2000): "Introduction: Sociolinguistic perspectives in small talk". In Justine Coupland, ed., 1-25. Small Talk. London: Longman. . (ed.) (2000): Small Talk. London: Longman.

Duranti, Alessandro. (1997): Antropología lingüística, Madrid: Cambridge University Press.

Fant, Lars (1989): "Cultural mismatch in conversations: Spanish and Scandinavian communicative behaviour in negotiation settings”. Journal of Linguistics 247-265. (1995): "Negotiation discourse and interaction in cross-cultural perspective: the case of Sweden and Spain”. In Konrad Ehlich and Johannes Wagner, eds., The Discourse of Business Negotiation. Walter de Gruyter, 177-201.

. (2006): "Rapport and identity management: a model and its application to Spanish dialogue”. In María Elena Placencia and Carmen García, eds., Politeness in the SpanishSpeaking World. London: Erlbaum Publishing, 335-387.

Forgas, Joseph (1999): “On feeling good and being rude: affective influences on language use and request formulations". Journal of Personality and Social Psychology 76 (6): 928-939.

Fraser, Brian (1990): “Perspectives on Politeness”. Journal of Pragmatics 14 (2): 219-236.

García Gómez, Antonio (2008): "Conflicting to be polite of being polite not to conflict: a social constructivist approach to the notion of face for the British and American culture”. Actas del XXIV Congreso Internacional de AESLA, 1341-1347.

Garcés, Pilar (1991): Estudio pragmático contrastivo del diminutivo: una propuesta metodológica. In Feli Etxebarría and Jesús Arzamendi, eds., Bilingüismo y Adquisición de Lenguas. Universidad del País Vasco: Bilbao. 247-257.

(1993): "Revisión crítica de algunos de los postulados de la teoría de la cortesía lingüística propugnada por Brown y Levinson”. Quaderns de Filología, Estudis Linguistcs 1: 43-62.

Gu, Yueguo (1990): "Politeness phenomena in modern Chinese”. Journal of Pragmatics 14: 237-257.

Haugh, Michael (2007): “The co-constitution of politeness implicature in conversation”. Journal of Pragmatics 39 (1): 84-110.

Heritage, John (1984): Structures of Social Action. Cambridge: Cambridge University Press.

Heritage, John and Douglas W. Maynard. (2006): "Problems and Prospects in the Study of Physician-Patient Interaction: 30 years of Research” Annual Review of Sociology 32: 351-374.

Hernández-López, Mariola and María Elena Placencia (2004): “Modos de conducir las relaciones interpersonales en interacciones de atención al público: El caso de las farmacias en Sevilla y Londres”. ELUA: Estudios de Lingüística de la Universidad de Alicante 18: 129-150.

Hickey, Leo (1991):“Comparatively polite people in Spain and Britain”. ACIS 4 (2): 2-6.

Hofstede, Geert (1994) Cultures and Organizations: a software of the mind: intercultural. London: Harper Collins. . (2001): Culture’s Consequences: Comparing Values, Behaviours, Institutions and Organizations Across Nations (2nd edition). Thousand Oaks, CA: Sage. . (2007): “A European in Asia”. Asian Journal of Social Psychology 10(1):16-26. 
House, Juliane (2000): “Understanding misunderstanding: a pragmatic-discourse approach to analyising mismanaged rapport in talk across cultures”. In Helen Spencer-Oatey, ed, Culturally Speaking. Managing Rapport through Talk Across Cultures, 145-164.

House, Juliane, Gabrielle Kasper and Steven Ross (2003): Misunderstanding in Social Life. Discourse Approaches to Problematic Talk. London: Pearson Education Ltd.

Kim, Min-Sun (1994): "Cross-cultural comparisons of the perceived importance of conversational constraints". Human communication research, 21 (1): 128-155.

Lehtinen, Esa (2007): “Merging doctor and client knowledge: on doctors' ways of dealing with clients' potentially discrepant information in genetic counseling”. Journal of Pragmatics 39: 389-427.

Locher, Miriam A. and Richar J. Watts (2005): "Politeness theory and relational work". Journal of Politeness Research 1: 9-13.

. (2006): "Polite behaviour within relational work: The discursive approach to politeness”. Multilingua, 25 (3): 249-267.

Matsumoto, Yoshiko (1988): "Reexamination of the universality of face: politeness phenomena in Japanese”. Journal of Pragmatics 12: 403-426.

Nieto y Otero, María Jesús (2003): “Afectividad y cortesía: análisis de conversaciones políticas”. En Diana Bravo, ed., Actas del primer coloquio del programa EDICE: La perspectiva no etnocentrista de la cortesía: identidad sociocultural de las comunidades hispanohablantes. Estocolmo: Programa EDICE, Universidad de Estocolmo, 240-256.

Pierce, P. F. (1996): "When the patient chooses: describing unaided decisions in health care" Human Factors 38 (2): 278-287.

Pizziconi, Barbara (2006): “Politeness”. In Keith Brown, ed., Encyclopedia of Language and Linguistics, Volume 9 (2nd ed.) Amsterdam: Elsevier, 679-684.

Placencia, María Elena (2004): "Rapport-building activities in corner shop interactions”. Journal of Sociolinguistics, 8: 215-245.

Placencia, María Elena and Carmen García (eds.) (2006): Politeness in the Spanish-Speaking World. London: Erlbaum Publishing.

Roter, Debra I. and Judith A. Hall (1992): Doctors Talking with Patients/ Patients Talking with Doctors: Improving Communication in Medical Visits. Westport, CT: Auburn House.

Sperber, Dan and Deidre Wilson ([1986] 1995): Relevance: Communication and Cognition. Oxford: Blackwell.

Steward, Moira (2003): "Evidence for the patient-centered clinical method as a means of implementing the biopsychosocial approach”. The Biopsychosocial Approach: Past, Present, Future. Rochester, NY: University of Rochester Press, 123-132.

Sydow Campbell, Kim (2005): "The Rapport Management Model: how physicians build relationships with patients” IEEE International Professional Communication Conference Proceedings, 422-432.

Sydow Campbell, Kim, Charles D. White and Diane E. Johnson (2003): "Leader-member relations as a function of rapport management”. Journal of Business Communication 40 (3): 170-194.

Sydow Campbell, Kim and Charles D. White (2007): "Necessary evils, (in)justice and rapport management”. Journal of Business Communication 44(2): 161-185.

Spencer-Oatey, Helen. (ed.) (2000): Culturally Speaking. Managing Rapport through Talk Across Cultures. London: Continuum. 
. (2008): Culturally Speaking. Culture, Communication and Politeness. London: Continuum.

Spencer-Oatey, Helen. and Jiang Wiang. (2003): “Explaining Cross-cultural pragmatic findings: moving from politeness maxims to sociopragmatic interactional principles (SIPs)”. Journal of Pragmatics 35: 1633-1650.

Ehlich, Konrad and Johannes Wagner (eds.) (1995): "The discourse of business negotiation”. Berlin: Mouton de Gruyter.

Watts, Richard J. (2005): "Linguistic Politeness Research: Quo Vadis?” In Richard J. Watts, Sachiko Ide and Konrad Ehlich, eds., Politeness in Language Studies in Its History, Theory and Practice. Berlin: Mouton de Gruyter, xi-xlvii.

Watts, Richard J., Sachiko Ide and Konrad Ehlich (eds.) (2005): Politeness in Language. Studies in its History, Theory and Practice (2nd ed.). New York: Mouton de Gruyter.

Young, Amanda and Linda Flower (2002): "Patients as Partners, Patients as ProblemSolvers". Health Communication 14 (1): 69-97.

\section{Appendix A:}

Transcription Conventions:

$\mathrm{P} \quad$ patient

D doctor

(( )) explanation of paralinguistic elements.

(...) inaudible/ irrelevant information.

[ ] overlapping utterances

? rising intonation

/ small pause

(1) pause specifying seconds in silence

$=$ contiguous utterances

::: syllable lengthening 